\title{
PEAT BOGS INFLUENCE ON RUNOFF PROCESS: CASE STUDY OF THE VYDRA AND KŘEMELNÁ RIVER BASINS IN THE ŠUMAVA MOUNTAINS, SOUTHWESTERN CZECHIA
}

B. J a n ský, J . K o c u m: Peat bogs influence on runoff process: case study of the Vydra and Kremelná River basins in the Sumava Mountains, southwestern Czechia. - Geografie-Sborník ČGS, 113, 4, pp. 383-399 (2008). - Specific part of wide complex of preventive measures against floods and extreme droughts could be procedures realized in river headstream areas. In order to increase a water retention in headwaters the detailed analysis of peat bogs hydrological function needs to be carried out. Suitable conditions for the research realization at present is related to an existence of several automatic water level gauges and utilization of modern equipment and methods in experimental catchments of the Otava River headstream area (Šmava Mts., southwestern Czechia), representing the core zone of a number of extreme floods in Central Europe. Thorough analyses of extreme runoff phases show more distinct discharge variability of streams draining peat land localities. For the retention potential assessment the detailed measurement of potential accumulation reservoirs, bathymetric mapping of bog pools and the detailed analysis of snow conditions as an important component of a rainfall-runoff process in headwaters is being pursued. The final part of the paper is consisted of suggestions of several unforceable measures implementation that could contribute to reduction of peak flows and to increase of water resources during extreme droughts in future.

KEY WORDS: retention potential - headstream area - flood protection - upper Otava River basin - runoff variability - drought - peat bogs hydrological function.

The presented research was funded by the project VaV SM/2/57/05 "Long-term Changes of River Ecosystems in Floodplains Affected by Extreme Floods", Research Plan MSM 0021620831 "Geographical Systems and Risk Processes in Context of Global Changes and European Integration" of the Czech Ministry of Education and the Charles University Grant Agency project No. 2371/2007 "Water Retention in River Headstream Areas as an Instrument of Integrated Flood Protection and Drought Problem Solving".

\section{Introduction}

In context of catastrophic floods and extreme droughts in recent years there is an urgent need of solving of flood protection issues and measures leading to discharge increase in dry periods, not using just classical engineering methods but also untraditional practices. There is a new strategy focusing on gradual increase of river catchment retention capacity including the realization of measures as runoff retardation and water retention increase in headstream areas.

In order to enhance the retention potential in headwaters the detailed analysis of peat bogs hydrological function needs to be done. The peat bogs influence on runoff conditions and other hydrographic and climatic characteristics is being assessed by detailed comparison of hydrological 
regimes in subcatchments with different peat land proportion. The research is concentrated to the upper Otava River basin (Vydra and Křemelná River basins) representing a territory with frequent occurrence of flood events and with a high heterogeneity in terms of physical-geographic and social-economic aspects. We can reason about the peat bogs influence on hydrological process also with respect to its affecting of water quality, respectively to ionic structure of water in periods of high or low discharges (Novák 1955, 1959; Onderíková, Štěrbová 1956; Oulehle, Janský 2003).

The problem of peat bogs hydrological function has not been so far fully solved despite a number of domestic and foreign projects and broad debates among experts. Opinions on such issues vary as it is evident in the literature that has been dealing with these questions already in the second half of the 19th century. The detailed analysis of various approaches was made by Ferda (1960). The so called "theory of sponge", which was in a literature acknowledged approximately from the last 60s, supposed the importance of peat land for its significant water retention and discharge regulating capability during high rainfall totals and its discharge heightening and runoff balancing in dry periods. From the last 70s studies that infirm the peat bogs retention function appear. They assert that only possible way to increase their retention capacity is to lower groundwater level by means of a drainage. Then these ameliorative hits were realized in a number of mountainous areas in Czechia. Since that time, the problem of drainage, respectively dyking of former drainage channels, has become the field for broad debates within a literature (Conway, Millar 1960; Burke 1967; McDonald 1973; Moklyak et al. 1975; Baird 1997; Holden et al. 2001; etc.). The detailed study of the literature representing both opinion poles was carried out by Holden et al. (2004).

Results of studies dealing with this research subject proved that water courses draining peat land areas show significant discharge variability and that the peat land influence on runoff regime balance had been overestimated in the past. It was found out that winter snow precipitations have a relatively low influence on discharge increase in summer period while summer rainstorms play a very significant role in this sense. While filling peat bogs up, runoff values increase rapidly. As well, during longer droughts, peat land does not play any positive role in hydrological terms, i.e. they do not feed water courses draining them. On the contrary, the past research projects state the hydrological regime improvement after peat bogs drainage and ameliorating. Peat land influence on water quality in water courses is assessed as unambiguously negative while intensity of affection is related to its area and volume in a catchment. The problem of pollution is further intensified in water reservoirs located in former peat land and moor areas.

Mentioned topic is currently studied in the upper Otava River basin (Janský, Kocum 2007a, 2007b and Kocum, Janský 2007a, 2007b). Outcomes of the research is considered to be used within the realization of specific effective flood protection measures in cooperation with all concerned institutions (including flood warning system, etc.). Assessment of peat bogs revitalizing measures influence of chosen localities on its hydrological regime change is also one of the project goals. Every single element of rainfall-runoff process, especially snow conditions in the study area, needs to be completely studied. In order to increase the retention potential in this area a qualified reference of measures being implemented at present by the Sumava Mts. National Park Management in connection with former ameliorative channels 
(made during communist regime) dyking needs to be done. The influence of peat bog localities on runoff process is assessed by detailed comparison of Vydra River and Křemelná River hydrological regimes (Otava River main sources with significantly different peat land proportion in their catchments). Profile Otava River - Rejštejn (catchment area $336.5 \mathrm{~km}^{2}$, T. G. Masaryk Water Research Institute - WRI GIS layers), long-term mean discharge $\mathrm{Q}_{\mathrm{a}}=7.56 \mathrm{~m}^{3} . \mathrm{s}^{-1}$ (Czech Hydrometeorological Institute - CHMI data) is the closing profile of the study area.

\section{Methodology}

More than 30 years ago the first results related to peat bogs hydrological function were presented within the study of CHMI in Prague (Ferda, Hladný, Bubeníčková, Pešek, 1971). In this project drainage and ameliorating of peat bog beds is recommended with regard to an improvement of their hydrological function. According to results from domestic and foreign literature it is stated that maximum discharges could be markedly reduced this way as a result of groundwater level decrease and consequently of extension the depth of peat bog surface layer for capturing causal rainfall totals. It is hereat adverted to other positive effects such as increase of forest stand accretion on drained areas (Vidal, Schuch 1963; Huikari 1963; Robertson, Nicholsen, Hughes 1963). This study is so far the last paper dealing with hydrological regime and water chemism in the upper Otava River basin focused on peat bog habitation.

In recent years the Otava River headstream area has become the study catchment of the research consisting partly in bathymetric mapping of organogenous lakes (bog pools, so called Sumava Mts. Moors) including specification of their main physical parameters and chemical composition, but especially in the initiation of thorough monitoring of Vydra and Křemelná River runoff regimes inclusive of assessment of various measures leading to their source areas retention potential increase. Very favourable conditions for the realization of this project currently bear on a better accessability to the study area and lengthening data time series but also on using quite modern equipment and methods.

At the end of 2005 six water level laths were installed in chosen profiles (Roklanský Brook, Modravský Brook, Filipohutský Brook, Vchynicko-tetovský Floating Channel - Rechle, Křemelná River above Prášilský Brook, Prášilský Brook above Křemelná River) in order to initiate hydrological observations. Till recent years water level values had been read constantly by local observers in a one day step (during melting process in spring period twice a day) in these profiles. Since summer period 2006 sixteen automatic ultrasound and hydrostatic pressure water level gauges with dataloggers for continual monitoring of water level fluctuation (11 in Vydra River basin, 5 in Křemelná River basin; Fig. 1) were subsequently installed beyond these profiles. Furthermore 4 water stage recorders within the CHMI water stage recorders network (Otava River - Rejštejn, Křemelná River - Stodůlky, Vydra River - Modrava, Hamerský Brook - Antýgl) and two profiles controlled by ČEZ group (Czech electropower company; Vchynicko-tetovský Floating Channel - Rechle and Mechov) became parts of the research network system. Besides, one meteorological station (observing precipitation, air temperature and humidity, solar radiation, wind speed and direction and soil temperatures) and 


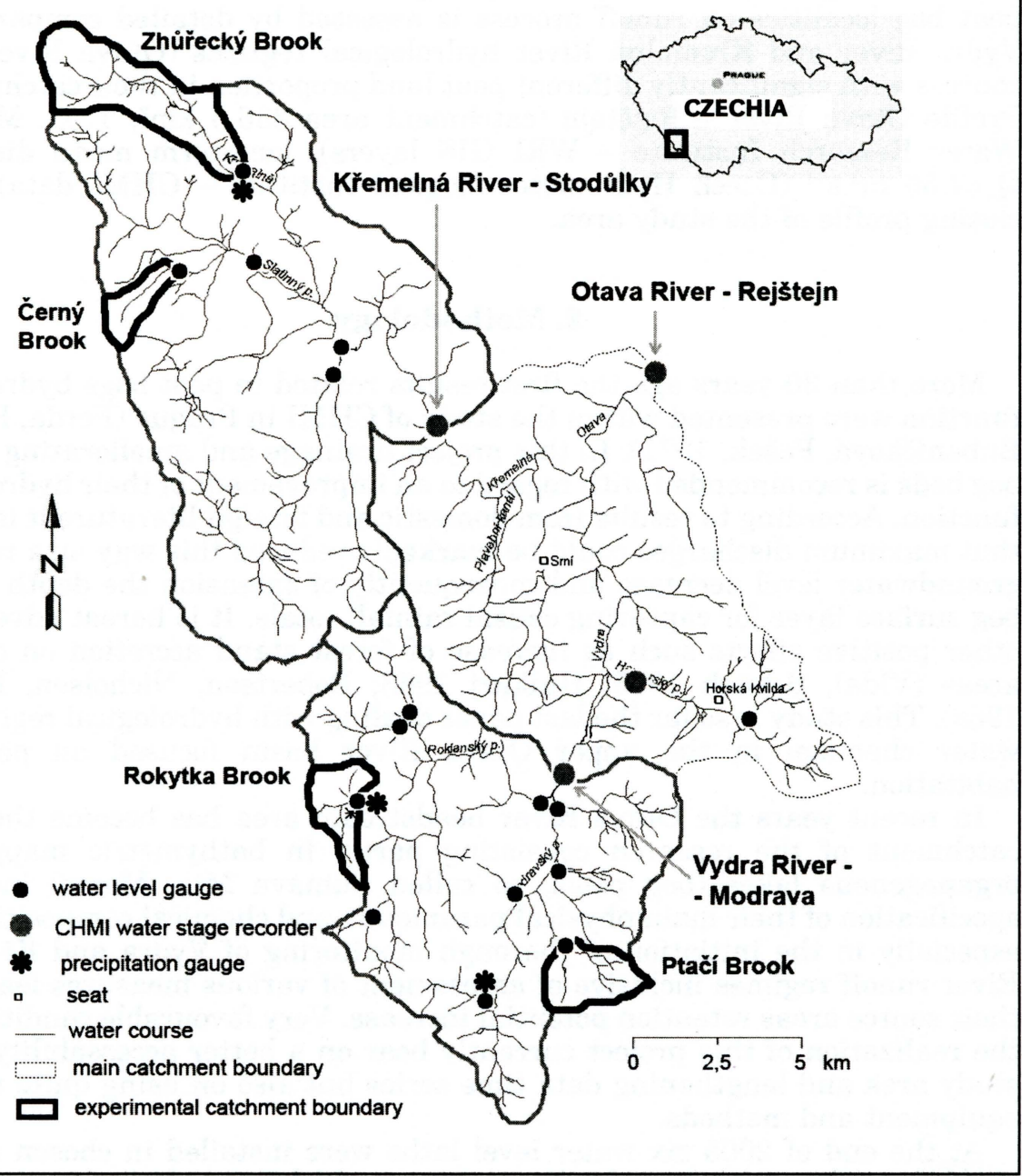

Fig. 1 - Localization of the Vydra River and the Křemelná River study basins with CHMI water stage recorders and experimental subcatchments with automatic water level gauges and shuttle precipitation gauges within the headstream area of Otava River (Otava River-Rejštejn closing profile)

two other shuttle precipitation gauges measuring in 10 minutes step were installed in the upper part of the Vydra River basin (Rokytka Brook; measures since 18 September 2006 excepting several months in winter periods) and Křemelná River basin (Zhůřecký Brook; measures since 29 March 2007). From technical reasons the amount of snowfall during winter periods cannot be measured meanwhile in mentioned profiles.

Measuring set from Fiedler-Mágr Company including registering and controlling unit of M4016 type, ultrasound or pressure sensor and GSM module for data transmission by means of GPRS network is used for continual water level monitoring in 10 minutes step with $1 \mathrm{~mm}$ accuracy. Data 
transmission in a one day interval or shorter depending on the dynamics of hydrological situation allows its operative solution and also regular control of whole measuring set function. In given profiles with installed water level gauges periodical discharge measurements using hydrometric propeller are carried out in order to construct an accurate consumption curves. Meanwhile, totally about 250 discharge measurements have been done.

Analyses of snow conditions, being a very significant element of rainfallrunoff process in Czech headstream areas, were carried out in the last two winter periods. Snow cover height and snow water equivalent (SWE) monitoring is done by point measurements with specific spatial distribution considering altitude, exposition, slope and vegetation cover. Acquired data are then digitalized and interpolated using suitable methods in GIS software (ArcMap, MapInfo, Surfer) so spatial distribution of snow reserves could be assessed. Information about accumulation dynamics is logged on the base of several measurements during winter period. Snow cover height and SWE measurement is carried out by means of the snow hydrometer SM 150-50 and exact position and altitude of measurement points is determined using GPS60CSx and GPS Leica.

The detailed survey of potential spaces for capturing causal rainfall totals and runoff retardation and successive assessment of potential accumulation reservoirs efficiency is carried out using automatic total geodetic station Levica TCRP1202 R1000.

\section{Results}

The main part of the project is the assessment of a hydrological regime in the Otava River basin headstream area including an evaluation of various measures for its retention potential enhancement and comparison of runoff variability in chosen subcatchments with regard to the peat land occurrence. In order to reach the goal the assessment and comparison of runoff variability partly in the Vydra and Křemelná River basins state profiles with relatively long time series, partly in experimental subcatchments with installed automatic ultrasound or hydrostatic pressure water level gauges, is carried out.

\subsection{Runoff regime analysis in the Vydra and Kř emelná River basins}

In order to compare hydrological regimes in basins of Otava River two main sources, Vydra and Křmelná Rivers, from the runoff variability point of view, the data of mean daily discharges in water stage recorders within the CHMI basic network are used. Two of these profiles are discussed: Vydra River - Modrava (catchment area $90.17 \mathrm{~km}^{2}$; WRI GIS layers), long-term mean discharge $3.483 \mathrm{~m}^{3} \cdot \mathrm{s}^{-1}$ (CHMI data), peat land proportion $38 \%$ (Ferda, Hladný, Bubeníčková, Pešek 1971) and Křemelná River - Stodůlky $\left(134.11 \mathrm{~km}^{2}, 3.722 \mathrm{~m}^{3} . \mathrm{s}^{-1}, 5 \%\right.$; Fig. 1). With respect to the fact that time series in studied profiles are not of the same length, the time period when both water stage recorders were in function is assessed. Accordingly the period 1 November 1999 - 31 October 2006 was analysed. This relatively short period could appear to be non-representative, yet basic statistical analyses of daily, monthly and annual time series were made and runoff was on the base 
Table 1 - Runoff variability characteristics in the Vydra River - Modrava and Křemelná River - Stodůlky profiles (1 November 1999 - 31 October 2006 period).

\begin{tabular}{|l|l|l|}
\hline Profile & Vydra R.-Modrava & Křemelná R.-Stodůlky \\
\hline catchment area $\left(\mathrm{km}^{2}\right)$ & 90.17 & 134.11 \\
long-term mean discharge $\left(\mathrm{m}^{3} \cdot \mathrm{s}^{-1}\right)$ & 3.483 & 3.722 \\
minimum discharge $\left(\mathrm{m}^{3} \cdot \mathrm{s}^{-1}\right)$ & 0.763 & 0.880 \\
maximum discharge $\left(\mathrm{m}^{3} \cdot \mathrm{s}^{-1}\right)$ & 55.100 & 64.600 \\
specific runnoff $\left(\mathrm{l} . \mathrm{s}^{-1} \cdot \mathrm{km}^{-2}\right)$ & 38.5 & 27.8 \\
minimum specific runnoff $\left(1 . \mathrm{s}^{-1} \cdot \mathrm{km}^{-2}\right)$ & 8.5 & 6.6 \\
maximum specific runnoff $\left(\mathrm{l}^{-1} \cdot \mathrm{km}^{-2}\right)$ & 611.0 & 481.7 \\
yearly discharge volume $\left(\mathrm{km}^{3}\right)$ & 0.1098 & 0.1174 \\
runoff height $(\mathrm{mm})$ & 1,218 & 875 \\
median & 2.030 & 2.410 \\
dispersion & 15.859 & 15.153 \\
mean divergence from mean value & 2.471 & 2.405 \\
authoritative divergence & 3.982 & 3.893 \\
decil divergence $\left(\mathrm{Q}_{\mathrm{d}}\right)$ & 0.601 & 0.502 \\
coefficient of variability $\mathrm{C}_{\mathrm{v}}\left(\mathrm{Q}_{\mathrm{d}}\right)$ & 1.143 & 1.046 \\
coefficient of variability $\mathrm{C}_{\mathrm{m}}\left(\mathrm{Q}_{\mathrm{m}}\right)$ & 0.421 & 0.392 \\
monthly discharge variability coef. $\mathrm{K}_{\mathrm{r}}$ & 5.048 & 3.686 \\
\hline
\end{tabular}

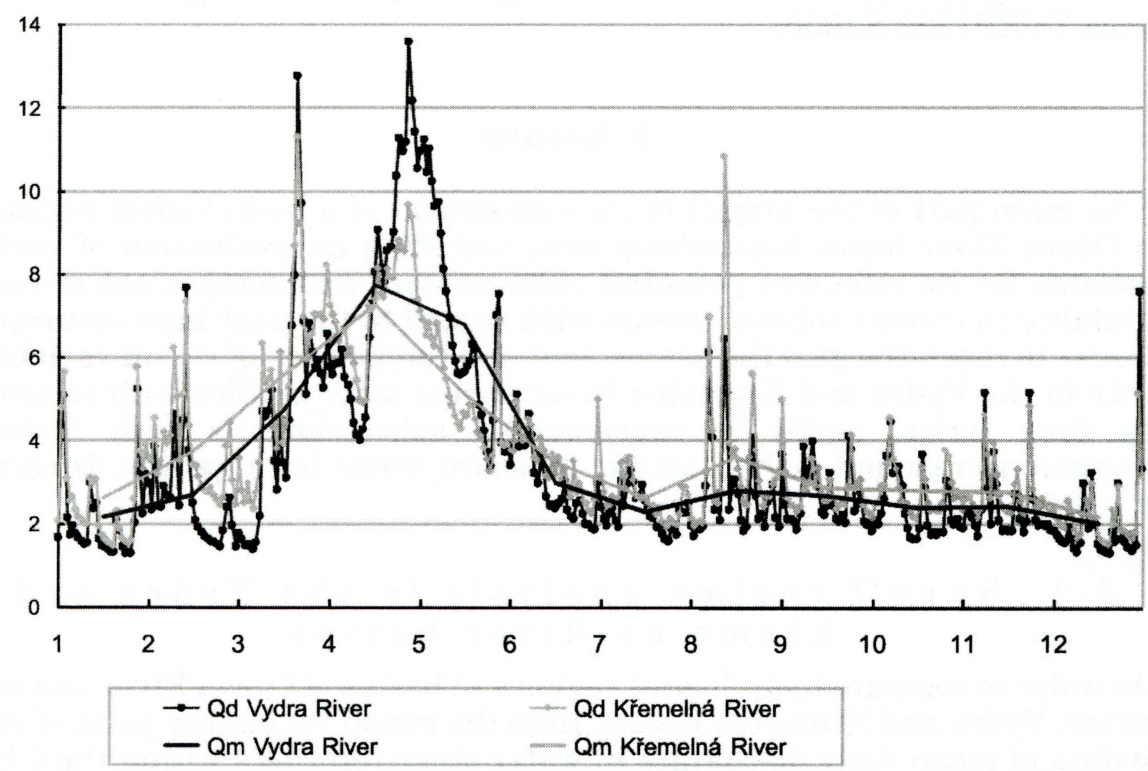

Fig. 2 - Long-term mean daily $\left(Q_{d}\right)$ and monthly discharges $\left(Q_{m}\right)$ in the Vydra River-Modrava and Křemelná River-Stodůlky profiles in 1 November 1999 - 31 October 2006 period. Axis $\mathrm{x}-$ months, axis $\mathrm{y}-\operatorname{discharge}\left(\mathrm{m}^{3} \cdot \mathrm{s}^{-1}\right)$.

of its variability graphically defined from the daily and monthly discharges point of view (Fig. 2) and described by characteristics presented in Table 1. On the basis of these outcomes it could be presumed that runoff variability appears to be slightly higher in the case of the Vydra River-Modrava profile. This fact is demonstrated especially by $K_{r}$ coefficient used for runoff assessment from the monthly discharge variability point of view. Higher 


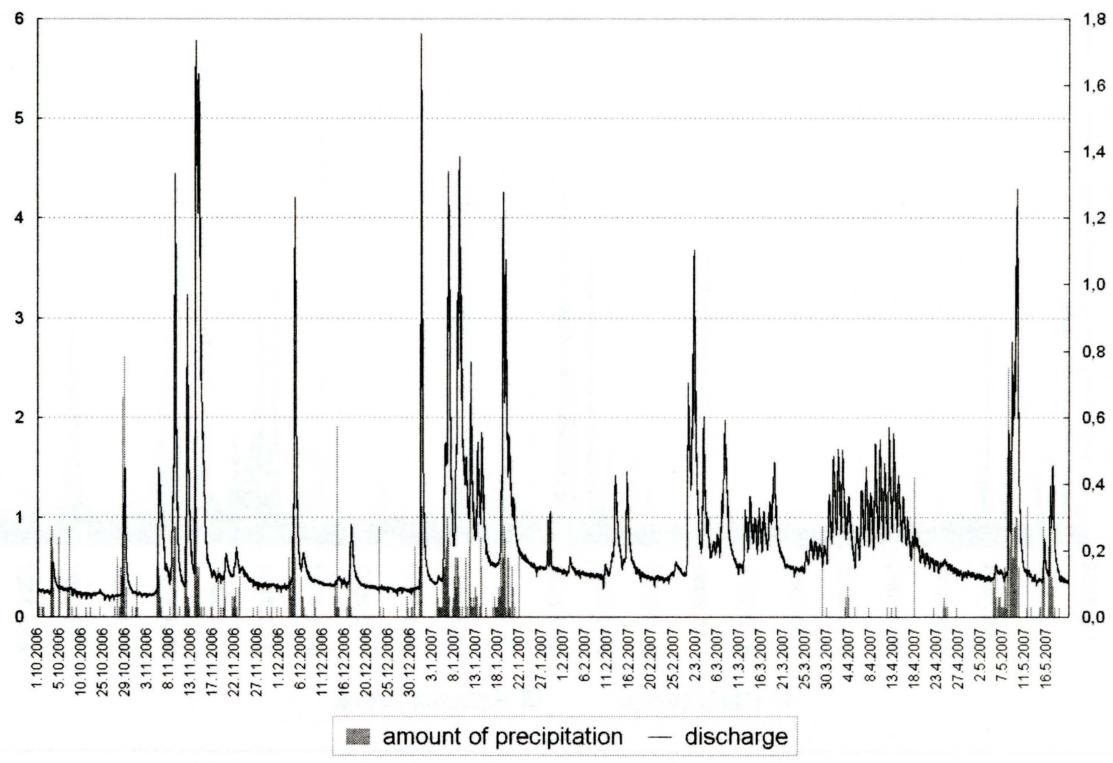

Fig. 3-Outcome from the automatic ultrasound water level gauge and shuttle precipitation gauge - runoff reaction to causal amount of precipitation in the Rokytka Brook profile (Vydra River headstream area) in 1 October 2006 - 20 May 2007 period (in 1 January 2007 - 28 March 2007 period precipitation gauge was out of service due to the technical reasons). Axis y left - amount of precipitation (mm), axis y right - discharge $\left(\mathrm{m}^{3} \cdot \mathrm{s}^{-1}\right)$.

runoff fluctuation is accordingly described in the profile closing the catchment with more significant peat land proportion. It is also evident by comparison of ratios of the maximum (April) and minimum (December) mean monthly discharge in the studied profiles which reach up to 3.83 in the Vydra River - Modrava profile, respectively 3.35 in the Křemelná River - Stodůlky profile.

\subsection{Runoff variability in experimental $\mathrm{subc}$ a t ch m e n t s}

In consequence of present short period of water level fluctuation monitoring using automatic water level gauges only partial results are kept at disposition. Preview of one of outcomes from the ultrasound water level gauge and shuttle precipitation gauge is presented in the Figure 3. It shows the discharge fluctuation of Rokytka Brook (Vydra River headstream area; catchment area $3.721 \mathrm{~km}^{2}$; WRI GIS layers) in relation to the amount of precipitation in 1 October 2006 - 20 May 2007 period. Significant discharge increase during spring period as a result of snow melting process in the catchment is very distinct. Nevertheless, striking runoff fluctuation (between 0.2 and $0.5 \mathrm{~m}^{3} \cdot \mathrm{s}^{-1}$ ) was registered also within the day.

As it was mentioned, in order to assess the peat bog localities and peat forming soils influence on the runoff regime variability two subcatchments within the upper Otava River study basin with significantly different peat land proportion were chosen. In the upper part of the Rokytka Brook 


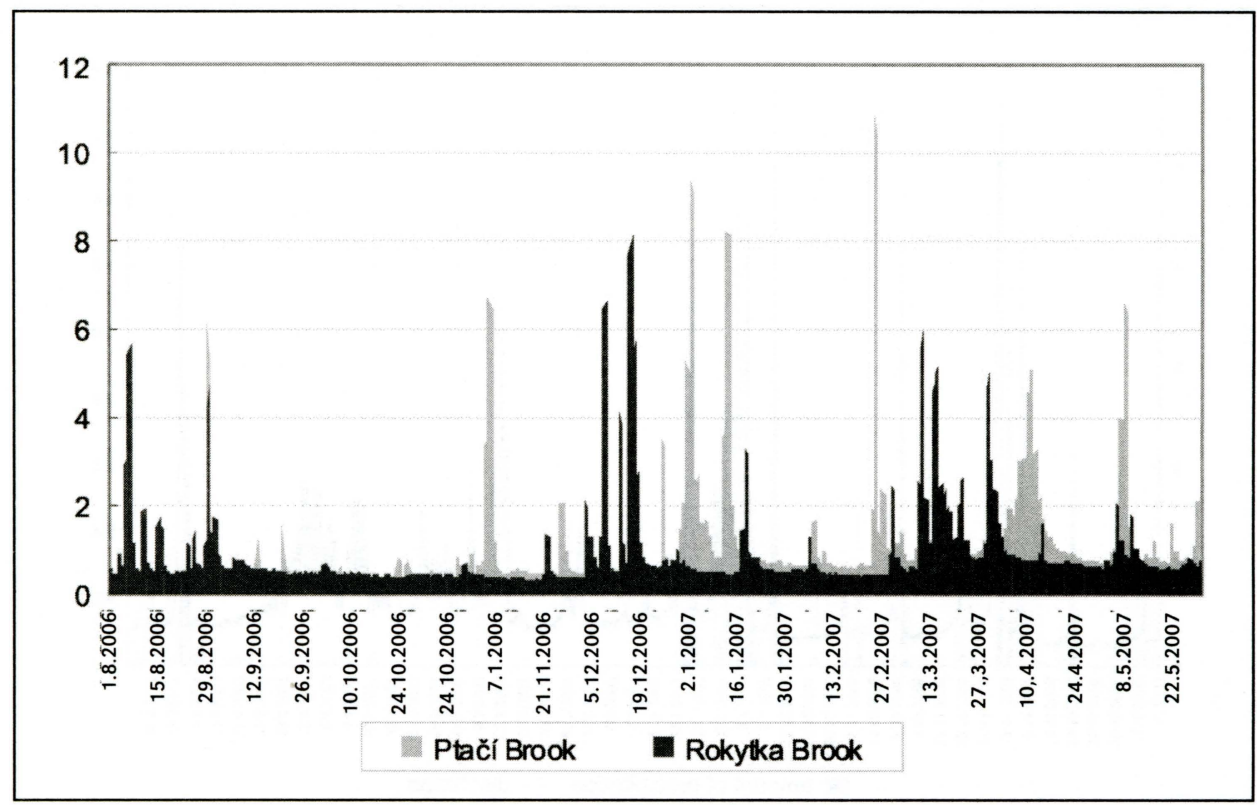

Fig. 4 - Comparison of runoff variability in two experimental subcatchments with a different peat land proportion (Rokytka Brook, Ptačí Brook) in 1 August 2006 - 31 May 2007 period. Axis y $-\mathrm{Q} / \mathrm{Q}_{\mathrm{p}}$.

catchment closed by the profile with installed automatic water level gauge a large complex of so called "Rokytecké Moors" is situated (approximately 55\% peat land proportion; Fig. 1). Much more sporadic occurrence of peat bog beds is fixed to the Ptačí Brook catchment (about $10 \%$ peat land proportion; catchment area $4.063 \mathrm{~km}^{2}$; WRI GIS layers). Slightly higher runoff variability in the case of Rokytka Brook is quite distinct from Figure 4. In doing so, discharge variability is besides absolute value of culmination defined especially by a peak flow frequency. Different rate of discharge of both water courses in monitored profiles is taken into account using $Q / Q_{p}$ ratio, where $\mathrm{Q}$ is actual 10-minutes discharge and $\mathrm{Q}_{\mathrm{p}}$ is mean discharge from the serie of all 10-minutes discharges from the whole monitoring period.

Through the exact study of runoff ascending and descending phases, concretely through the analysis of runoff reaction to causal rainfall (interval between maximum 10-minutes amount of precipitation and corresponding peak flow) during several rainfall situations within the monitoring period, more significant peak flow retardation in the Zhưřecký Brook profile (Fig. 1; about 4:40 hours in average; catchment area $13.946 \mathrm{~km}^{2}$; WRI GIS layers) compared to the Rokytka Brook profile (about 3:20 hours) was determined. It signifies higher water retention potency in the catchment with distinctively lower peat land proportion. Mentioned claims necessarily demand stronger reliance in terms of longer data time series and detailed analyses of a larger number of namely extreme rainfall situations.

To sum it up, detailed analyses of extreme runoff phases show higher frequency of peak flows and their shorter reaction to causal rainfall in case of highly peaty areas, therefore more distinct runoff variability of streams draining peat land localities and peat forming soils. Continuously much more 


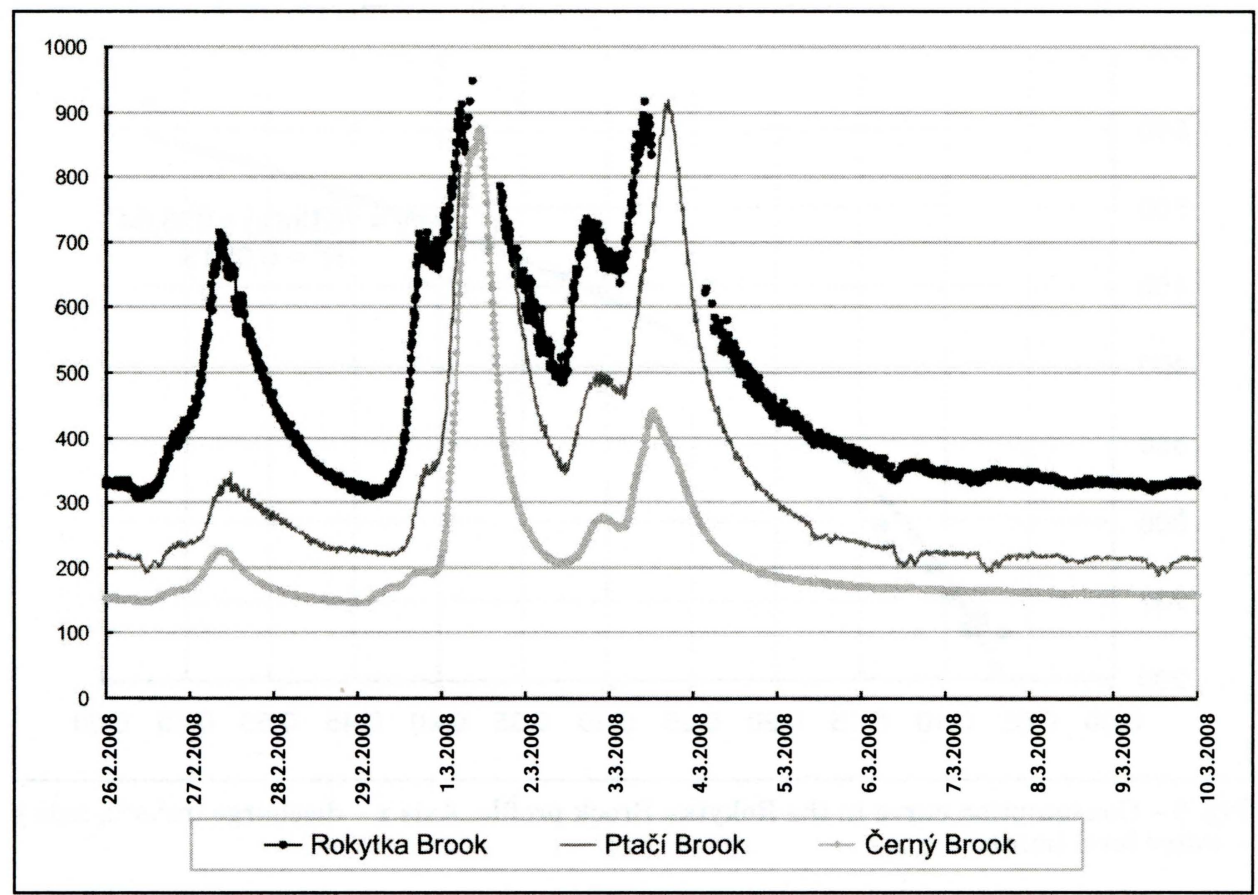

Fig. 5 - Water level fluctuation in three model subcatchments with different peat land proportion during the extreme flood situation in March 2008. Axis y - water level (mm).

detailed studies of hydrological and climatic data time series need to be done, especially reaction analyses of runoff from several peat bog localities in relation to rainfall duration, intensity and spatial distribution in monitored catchments by means of thorough study of its ascending and descending phases.

Hydrological monitoring in above mentioned watercourses is completed by the ionic balance including carbon and oxygen isotopes balance observing in 2008 hydrological year (cooperation with Czech Geological Survey) in order to make the precise separation of runoff phases by means of anion deficiency. Twice a month the atmospheric deposition samples and water samples are subscribed in relation to the monitored discharges.

\subsection{Extreme flood event analysis in model $\mathrm{subcatch}$ ments}

In order to compare the runoff conditions of areas with different physicalgeographic parameters during an extreme runoff situation, flood event at the beginning of March 2008 was partly analysed in three experimental subcatchments. Their choice was concentrated mainly on the peat land proportion in their territories. To reach the goal, within these three localities one catchment with very high proportion of peaty areas (Rokytka Brook; approx. $55 \%$ ) and one with very low value (mineral Černý Brook catchment; about $5 \%$ proportion of peat land; catchment area $2.419 \mathrm{~km}^{2}$; WRI GIS layers) were chosen. The distribution of moor areas within the catchment of Ptačí Brook is also quite low (see Fig. 1). 


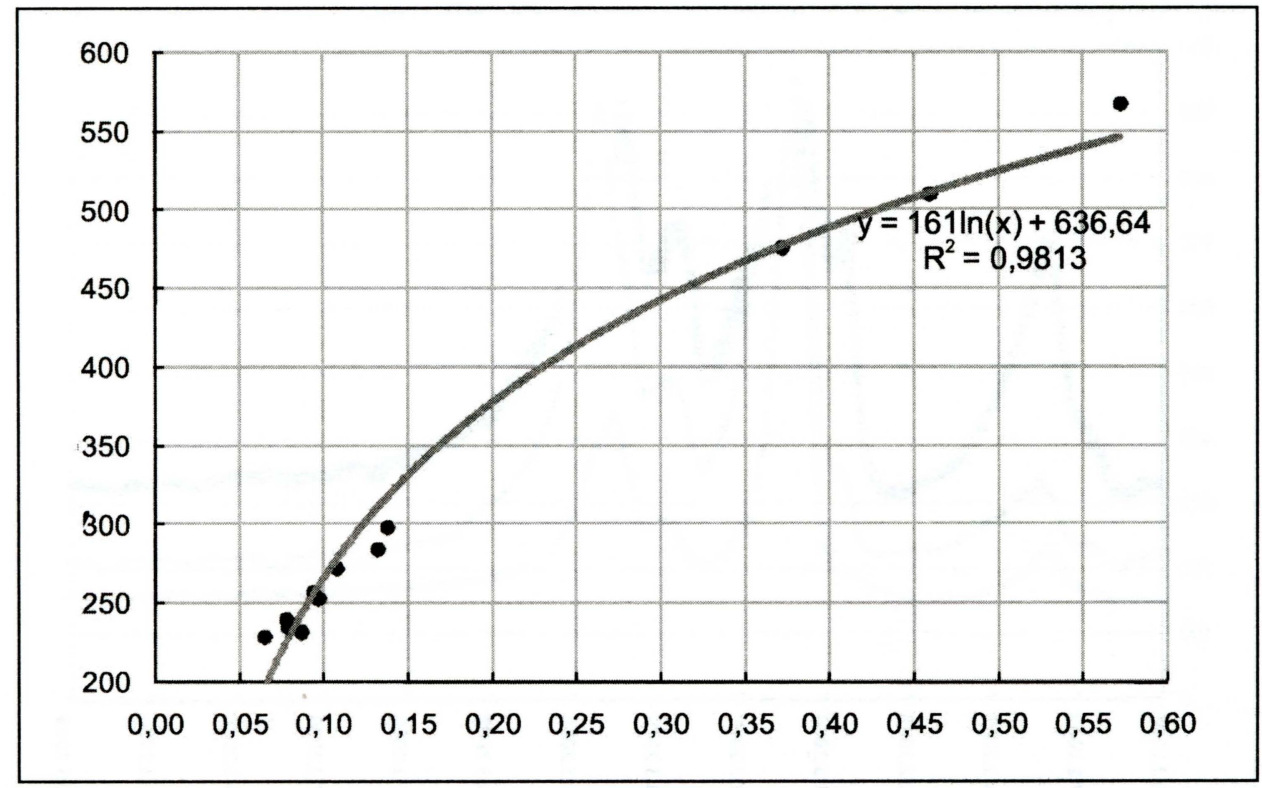

Fig. 6 - Consumption curve in the Rokytka Brook profile. Axis $\mathrm{x}$ - discharge $\left(\mathrm{m}^{3} \cdot \mathrm{s}^{-1}\right)$, axis y - water level (mm).

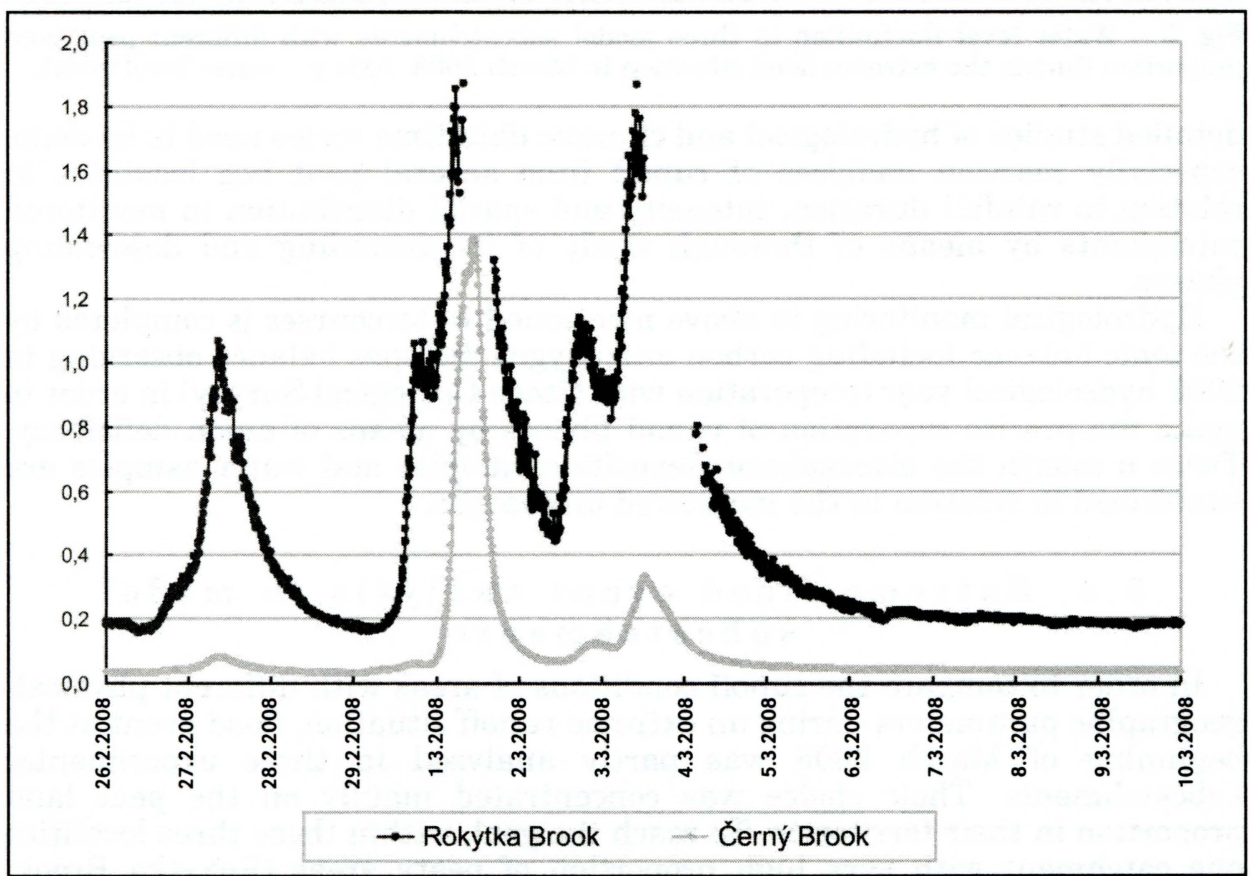

Fig. 7 - 10-minutes discharges in two model subcatchments with different peat land proportion during the extreme flood event in March 2008 (highly peaty area is represented by the Rokytka Brook catchment). Axis y - discharge $\left(\mathrm{m}^{3} \cdot \mathrm{s}^{-1}\right)$. 
The extreme amount of precipitation which affected a large territory of Europe early in the year 2008, known as Emma atmospheric low pressure, became very intensive especially in this study area. The runoff reaction on such an extreme rainfall totals in headwaters is generally very rapid and is demonstrated even by the graph in Figure 5. Water level fluctuation in three study profiles with installed automatic gauges for discharge monitoring quite apparently show very similar references mentioned above in the paper higher runoff variability in the case of a highly peaty area, even during such an extrem hydrological situation. Corresponding discharge values calculated using consumption curves (Fig. 6) in two out of three observed profiles are even more evident (see Fig. 7). Consumption curves are described by considerably high reliability values. The existence of periods with missing discharge data is caused by an enormous extremity of this event.

\subsection{Snow conditions analysis}

Even snow conditions in a catchment, as it was already mentioned, form very important phenomenon in our mountainous river headstream areas. Their detailed analysis represents a necessary basis for correct assessment of runoff formation in these areas and for truthful integration of this intricately quantificating element into hydrological processes modelling.

In February 2007 and February and March 2008 the detailed snow survey in the experimental subcatchments closed by profiles with automatic water level gauges (Rokytka Brook, Ptačí Brook and Černý Brook catchments) in the upper part of the Vydra River and Křemelná River basins, was carried out. Using snow laths and snow hydrometers the snow cover height and SWE was mapped in order to describe conditions for snow accumulation dynamics in this territory. For example, in the Ptačí Brook catchment with an area of $4.063 \mathrm{~km}^{2} 44$ point measurements were done (it corresponds to the measurement density of approximately 11 points $/ \mathrm{km}^{2}$ of an area). Character of snow cover occurrence is characteristic by a very significant time and spatial variability (Fig. 8). For the process of point data interpolation the IDW (Inverse Distance Weighted) method, where various values of input parameters were tested, was used. While the snow cover height in February 2007 in the lowest part of the Vydra River catchment (Modrava - $980 \mathrm{~m}$ a.s.l.) reached up to about 30 centimetres, values in the highest parts of the catchment $(1,330 \mathrm{~m}$ a.s.l.) were oscillating around $90 \mathrm{~cm}$. CHMI station Churáňov (1,118 $\mathrm{m}$ a.s.l.) was measuring in the time of a field survey around $30 \mathrm{~cm}$ of the snow cover. The situation one year later (February 2008) was even more variable. While the snow cover thickness was moving around 30 to $50 \mathrm{~cm}$ in the lowest parts of the above mentioned catchment, values measured in the source area close to the border with Germany were reaching up to about $150 \mathrm{~cm}$ (Kocum, Janský 2008).

Snow conditions survey in experimental subcatchments confirmed the existence of a considerable difference in the amount of accumulated snow storage not just in relation to an altitude but also to a vegetation cover, especially between open and forest areas. It indicates the circumstance which is difficult to be afflicted by measurements carried out usually on state meteorological stations. Along with this fact, very significant variability of snow storages on different localities of a similar character and altitude was proved. It gives an evidence about a considerable complexity of the snow cover accumulation process and its significant dependance on a number of factors. 


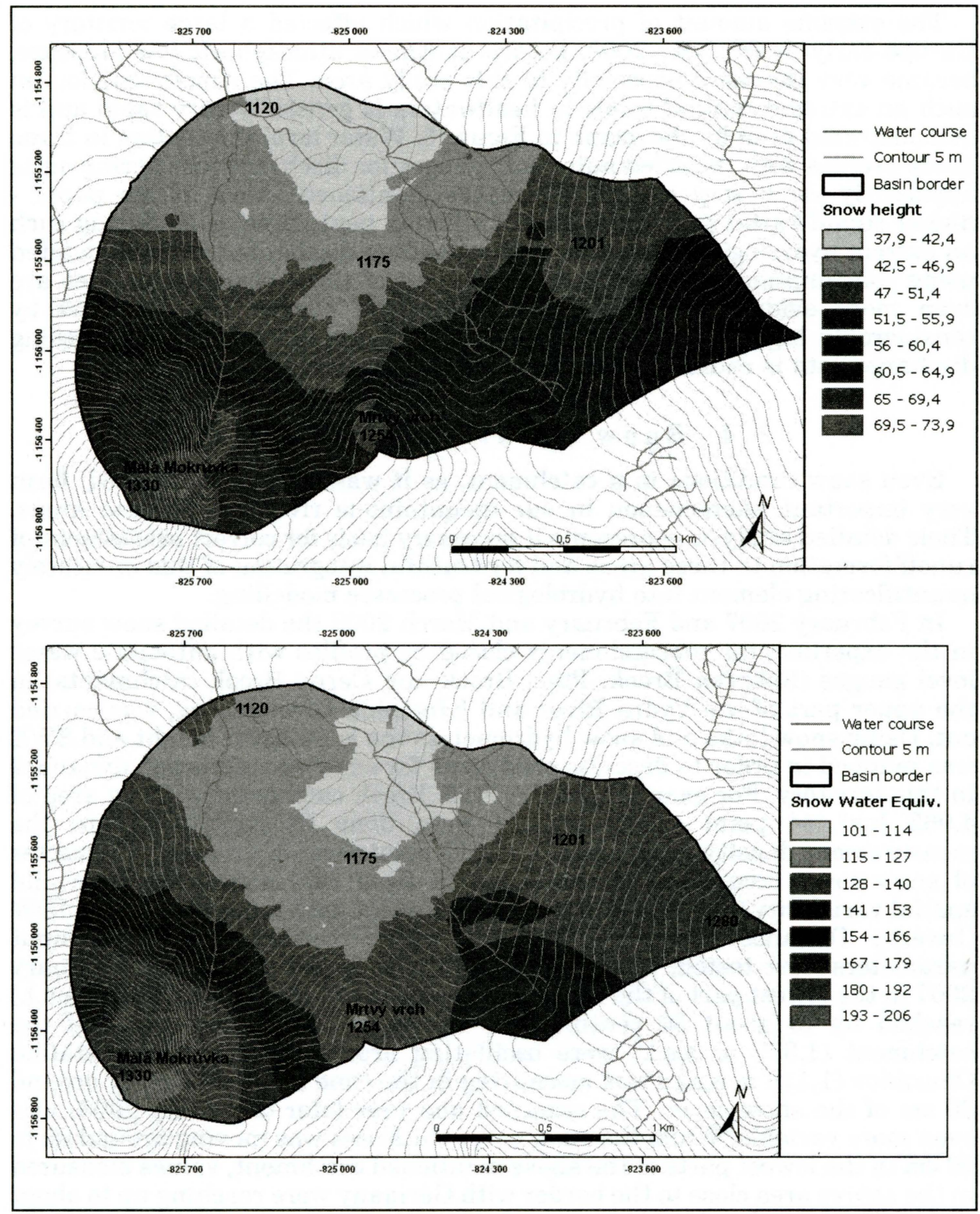

Fig. 8 - Spatial distribution of snow cover height (top, in $\mathrm{cm}$ ) and snow water equivalent (down, in mm) in the Ptačí Brook catchment on the 13 February 2007 (M. Jeníček). Data: Database DMÚ25 - VGHMÚř (http://geoportal.cenia.cz), DIBAVOD WRI. Coordinate system: S-JTSK.

On the base of the runoff analysis in the Rokytka Brook profile it could be stated that 2007 hydrological year was very specific from the occurrence and amount of snow storages point of view, in the same way as the snow melting runoff. Above-average air temperatures, especially in January 2007, did not make the creation of usual amount of snow storages possible and represented 
the cause of markedly above-average runoff in this month. Year 2008 was from the character of winter and spring runoff point of view much closer to an average. Because of the fact that last two winter periods were in term of snow storages below the average and therefore inconvenient to detailed analyses and qualified conclusions the thorough field survey and monitoring of snow cover and its evolution dynamics in following snow period, especially during the process of snow melting in spring months, is considered to be continuing. In following years remote sensing methods for snow cover estimation is planned to be used.

The above described facts are the most important aspects that are necessary to be taken into account within the process of calculating the total water volume retained in snow storages. It is needed to consider the fact that on the base of data from CHMI climatic stations it is not possible to assess the real state of snow conditions in the study catchment in order to determinate the most accurate prognosis of runoff from snow cover. Partial analyses of correlation between a snow cover height, respectively SWE and altitude together with other physical-geographic factors acknowledge our hypothesis that spatial distribution of a snow cover including all its parameters is very variable, especially in mountainous basins.

\section{Conclusions}

All of the issues related to various possibilities and measures leading to river headstream areas retention capacity increase should be discussed by experts in various fields taking into account objectives and priorities of a regional and local significance (Buček, 1998; Knapp, 2000; Kolejka, 2003). Such a discussion could result for example in the introduction of suitable landscape elements or gradual modification of land use in areas playing various roles within the flood control (Kovár. Sklenička, Krrovák, 2002). However, this cannot be applied to national nature reserves that should be left free of any human interventions.

Present outcomes from automatic water level gauges installed in the study basin of upper Otava River persuade us of the fact that data measured this way make it possible to assess peat bogs hydrological function very in detail. Especially comparison of those parts of catchment where revitalizing measures took place, respectively other parts where ameliorative adjustments of mountainous peat bogs were implemented in the last $70 \mathrm{~s}$, needs to be carried out. Continual records of water level and corresponding discharge values offer an extraordinary database for detailed analyses of flood waves ascending and descending phases, respectively for assessment of peat bogs and peat forming soils influence on runoff process during dry periods. Qualified conclusions from field survey can be formulated after analyses of longer data time series. Nevertheless, partial outcomes from present studies quite conclusively present more distinct runoff variability in profiles closing catchments with very significant peat land proportion mainly with respect to higher frequency of peak flows. Negative effect of peat bog localities on river headstream area hydrological regime was confirmed by thorough study and comparison of runoff reaction to causal rainfall totals in experimental catchments as well. Longer reaction interval adverting to more significant causal rainfall amount retention in the catchment was determined in the case of the catchment with less peat land proportion. 
The problem of peat bogs hydrological function depends on a number of factors, especially on its type, health state, rate of anthropogenic impact, etc. The assessment of peat land hydrological regime and considering the influence of chosen physical-geographic factors is currently being carried out. At present the determination of peat bog revitalizing measures influence on their runoff regime is in process. The peat land influence on hydrological regime is being considered also with respect to the ionic content and carbon and oxygen isotopes balance of water in periods of low or high discharges. First results support above mentioned claims and outcomes. In addition to considering dyking of former drainage channels and focusing on recovery of vegetation health state having a positive influence on retention capability in a catchment the possible former accumulation reservoirs (used for wood floating in the past) restoration with potential function as dry polders is in the process of evaluating (Janský 2006; Janský, Kocum 2008). Using complex system of hydrological models with semi-distributed approach the simulation of runoff process and the assessment of the effectiveness of these reservoirs could be made. Implementation of such unforceable measures could contribute to reduction of peak flows and to increase of water resources during extreme droughts in future. In addition, the running of mentioned profiles with installed automatic gauges within the flood warning system in cooperation with CHMI is cogitated.

Partial results from the snow conditions survey in representative subcatchments confirmed the existence of a considerable variability in the amount of accumulated snow storage not just in relation to an altitude but also to a vegetation cover and other factors. Along with this fact, acquired data in the form of graphical outcomes prove very significant variability of snow storages on different localities of a similar altitude and character which gives an evidence about a high complexity of the snow cover accumulation process and its significant dependance on a number of physical-geographic factors. The above described facts represent the most important aspects that are necessary to be taken into account within the calculating of the total water volume retained in snow storages. Detailed field survey and monitoring of snow conditions including remote sensing methods are planned to be continuing during the next winter period.

\section{References:}

BAIRD, A. J. (1997): Field estimation of macropore functioning and surface hydraulic conductivity in a fen peat. Hydrological Processes, 11, pp. 287-95.

BUČEK, A. et al. (1998): Analýza povodňových událostí v ekologických souvislostech. Unie pro řeku Moravu, Brno, $81 \mathrm{p}$.

BURKE, W. (1967): Principles of drainage with special reference to peat. Irish Forestry, 24, pp. 1-7.

CONWAY, V. M., MILLAR, A. (1960): The hydrology of some small peat-covered catchments in the northern Pennines. Journal of the Institute of Water Engineers, 14, pp. 415-424.

FERDA, J. (1960): Hydrologický význam horských vrchovištních rašelinište. Sborník ČSAZV-Lesnictví, No. 10, Praha, pp. 835-856.

FERDA, J., HLADNÝ, J., BUBENIČKOVÁ, L., PEŠEK, J. (1971): Odtokový režim a chemismus vod v povodí Horní Otavy se zaměřením na výskyt rašelinište. Sborník prací HMÚ, 17, HMÚ, Praha, pp. 22-126.

HOLDEN, J., BURT, T. P., COX, N. J. (2001): Macroporosity and infiltration in blanket peat: the implications of tension disc infiltrometer measurements. Hydrological Processes, 15, pp. 289-303.

HOLDEN, J., CHAPMAN, P. J., LABADZ, J. C. (2004): Artificial drainage of peatlands: 
hydrological and hydrochemical process and wetland restoration. Progress in Physical Geography, 28, No. 1, pp. 95-123.

HUIKARI, O. (1963): Über den Einfluss der Grabenabstande auf den Wasserhaushalt der Torfboden in Sphagnum-Mooren, Verdunstung und Abfluss des Wassers. Ref. Intern. Torfkongress, Leningrad.

JANSKÝ, B. (2006): Water Retention in River Basins, AUC-Geographica, XXXVIII, No. 2, pp. 173-183.

JANSKÝ, B., KOCUM, J. (2007a): Hydrologická funkce rašeliništ. In: Langhammer, J. (ed.): Změny v krajině a povodňové riziko. Sborník příspěvků semináře Povodně a změny v krajině. PřF UK, MŽP ČR, Praha, pp. 173-182.

JANSKY, B., KOCUM, J. (2007b): Retenční potenciál v pramenných oblastech toků. In: Langhammer, J. (ed.): Povodně a změny v krajině. MŽP ČR, PřF UK, Praha, pp. 307-316.

JANSKÝ, B., KOCUM, J. (2008): Retence vody v pramenných oblastech toků a na území říční nivy. In: Pithart, D., Benedová, Z., Křováková, K. (eds.): Ekosystémové služby říční nivy. Ústav systémové biologie a ekologie AV ČR, Třeboň, pp. 101-108.

KNAPP, R. (2000): Protipovodňová ochrana. Zátopová území řek Moravy a Bečvy. Geoinfo, 7, No. 6, pp. 28-32.

KOCUM, J., JANSKÝ, B. (2007a): Retention potential in river headstream areas. Sborník příspěvků mezinárodního kurzu UNESCO Ecohydrological Approaches to Wise Use, Restoration, Management and Conservation of Wetlands. Třeboň, pp. 8-16.

KOCUM, J., JANSKY, B. (2007b): Water retention in river headstream areas as an instrument of integrated flood protection and drought problem solving. In: Earth: Our Changing Planet. Conference proceedings IUGG XXIV General Assembly Earth: our changing planet. USMA, Perugia, Italy, p. 887.

KOCUM, J., JANSKÝ, B. (2008): Possibilities of headwaters retention potential enhancement - case study upper Otava River basin. In: Brilly, M., Šraj, M. (eds.): XXIVth Conference of the Danubian Countries on the Hydrological Forecasting and Hydrological Bases of Water Management, CD-ROM. 2.-4. June 2008, Slovenian National Committee for the IHP UNESCO, Ljubljana.

KOLEJKA, J. (2003): Geoekologické aspekty zmírňování povodňových škod. Geografie-Sborník ČGS, 108, No. 1, Praha, pp. 1-13.

KOVÁR, P., SKLENIČKA, P., KŘOVÁK, F. (2002): Vliv změn užívání krajiny na její ekologickou stabilitu a vodní režim. In.: Extrémní hydrologické jevy v povodích. ČVƯT, ČVVS, Praha, pp. 99-106.

McDONALD, A. (1973): Some views on the effects of peat drainage. Scottish Forestry, 27, No. 315-27.

MOKLYAK, V. I., KUBYSHKIN, G. P., KARKUTSIEV, G. N. (1975): The effect of drainage works on streamflow. Hydrology of marsh-ridden areas, Proceedings of the Minsk symposium, June 1972. IAHS Studies and Reports in Hydrology, 19. Unesco Press, Paris, pp. 439-46.

NOVÁK, M. (1955): Huminové vody ve vodách údolních nádrží. Vodní hospodářství, 5, No. 4 , pp. 127-128.

NOVÁK, M. (1959): Výzkum kvality vody v údolní nádrži Lipno. Vodní hospodářství, 9, No. 9, pp. 378-383.

ONDERÍKOVÁ, V., ȘTĚRBOVÁ, A. (1956): Príspevok k biologii a chemizmu Oravskej nádrže. Vodní hospodár̆́rství, 6, No. 2, pp. 46-51.

OULEHLE, F., JANSKÝ, B. (2003): Limnologie a hydrochemismus v NPR Rejvíz. In.: Jezera Ceské republiky (Současný stav geografického výzkumu). PřF UK, Praha, pp. 93-108.

ROBERTSON, R. A., NICHOLSEN, I. A., HUGHES, R. (1963): Studien über den Abfluss eines Moores. Ref. Intern. Torfkongress, Leningrad.

VIDAL, H., SCHUCH, M. (1963): Ergebnisse vergleichender Abfluss und Grundwasserbeobachtungen auf einer unberührten bzw. kultivierten Hochmoorflache in den südlichen Chiemseemooren im Abflussjahr 1962. Bayer. Landw. Jahrbuch 40, No. 6, pp. 721-736. 


\section{VLIV RAŠELINIŠŤ NA ODTOKOVÝ PROCES: PŘÍPADOVÁ STUDIE POVODÍ VYDRY} A KŘEMELNÉ NA ŠUMAVĚ (JIHOZÁPADNÍ ČESKO)

V souvislosti s výskytem katastrofálních povodní v povodí Odry a Moravy v roce 1997 a v povodí Labe v letech 2002 a 2006 se objevuje naléhavá potřeba řešení širokého komplexu otázek protipovodňové ochrany, a to nejen klasickými inženýrskými metodami, ale i netradičními postupy. $V$ popředí zájmu společnosti se objevuje nová strategie ochrany před povodněmi zaměřená na postupné zvyšování retenční kapacity povodí včetně jeho pramenných oblastí. Všechny otázky související s rozmanitými možnostmi a opatřeními k dosažení tohoto cíle by měly být posouzeny na základě kvalifikované diskuze odborníků různého zaměření vzhledem $\mathrm{k}$ cílům a prioritám, které mají význam nadregionální, místní či lokální (např. Buček 1998, Knapp 2000, Kolejka 2003). Přirozený odtokový proces je ovlivňován člověkem již u samého jeho zrodu, tedy $\mathrm{v}$ pramenných oblastech tokù, kde lze realizovat četné postupy související se zpomalováním odtoku a zvyšováním retence vody v území (Janský 2006; Janský, Kocum 2008).

Pro zvýšení retenčního potenciálu zdrojových částí povodí je třeba podrobně analyzovat hydrologickou funkci horských vrchovište spočívající v detailním porovnání odtokových režimů $\mathrm{v}$ povodích $\mathrm{s}$ rozdílným stupněm zrašelinění a kvalifikovaně posoudit význam opatření souvisejících $\mathrm{s}$ hrazením původních melioračních kanálů. Velmi dobré podmínky pro realizaci tohoto výzkumu poskytují povodí Vydry a Křemelné na Šumavě (jihozápadní Ćesko), kde byly instalovány automatické ultrazvukové a tlakové hladinoměry a klimatické stanice s telemetrickým přenosem dat (obr. 3). Otázka vlivu rašeliništ na odtokový proces, především pak vlivu revitalizačních opatření rašeliništních lokalit na hydrologický režim toků, které je odvodňují, není přes řadu tuzemských i zahraničních projektů a mnohé spory vedené v odborných kruzích doposud uspokojivě vyřešena. Tzv. „houbová teorie“, která byla v domácí i světové literatuře uznávána přibližně do 60 . let 20 . století, předpokládala, že rašeliniště zadržují vodu při vysokých srážkách (povodňových průtocích) a naopak v období sucha průtoky nadlepšují a podílejí se tak na vyrovnávání odtoku. Od 70 . let 20 . stol. se objevují práce, které retenční funkci rašeliništ zpochybňují a za jedinou možnost zvýšení jejich retenční kapacity doporučují snížení hladiny podzemní vody pomocí odvodnění. Tyto meliorační zásahy byly poté provedeny v řadě horských oblastí Česka. Problematika odvodnění, resp. hrazení původních melioračních kanálů odvodňujících rašeliniště, se od té doby stala podnětem pro široké diskuse v rámci zahraniční i tuzemské odborné literatury (Holden et al. 2004).

$\mathrm{Na}$ podkladě dosavadních výsledků, grafických výstupů i statistických analýz, lze usoudit, že variabilita odtoku je vyšší v případě profilù uzavírajících povodí s významným podílem zrašelinělých a rašeliništních půd než závěrových profilů povodí $\mathrm{s}$ minimálním zrašeliněním. Fakt, že existence rašeliništ má negativní vliv na odtokový proces, zvláště během extrémních hydrologických situací jako jsou povodně a období sucha, byl dokázán jednak detailní statistickou analýzou průměrných denních a měsíčních průtoků ve státních profilech Vydra-Modrava a Křemelná-Stodůlky (obr. 1, 2 a tab. 1), a jednak porovnáním odpovídajících si vzestupných a poklesových fází odtoku $\mathrm{v}$ experimentálních profilech s různým stupněm zrašelinění (obr. 4). Variabilita odtoku je přitom kromě absolutní hodnoty kulminace definována především četností výskytu kulminačních průtoků. Rozdílná vodnost toků ve sledovaných profilech je zohledněna použitím poměru $Q / Q_{p}$, přičemž $Q$ je okamžitý desetiminutový průtok a $Q_{p}$ je aritmetický průměr z řady desetiminutových průtoků za celé sledované období. Podrobným rozborem jednotlivých fází odtoku, konkrétně analýzou reakce odtoku na př́činnou srážku (doba mezi výskytem max. desetiminutového úhrnu srážek a odpovídajícím kulminačním průtokem) během několika srážkových situací v rámci sledovaného období, bylo zjištěno významnější zpoždění kulminace odtoku a tedy vyšší schopnost retence vody v povodí s výrazně nižším zastoupením rašeliništ. Podobných výsledků bylo dosaženo při analýze příčinných srážek a odtokové odezvy u několika epizod povodňových průtoků ve třech dílčích experimentálních povodích - Rokytky, Ptačího potoka a Černého potoka (obr. 5 a 7). Extremita odtoku byla i zde př́mo závislá na stupni zrašelinění daného povodí. Hydrologický monitoring $\mathrm{v}$ modelových povodích je doplněn i sledováním iontové bilance rašeliništ včetně bilance uhlíku a izotopů kyslíku za účelem detailní separace jednotkového hydrogramu pomocí aniontové deficience.

Důležitým fenoménem tvorby odtoku v pramenných oblastech českých toků je v celkové roční bilanci sezónní sněhová pokrývka, která představuje v prostoru a čase poměrně těžko 
kvantifikovatelný prvek. Charakter jejího výskytu se vyznačuje vysokou mírou časové a prostorové variability (obr. 8). Sněhoměrná pozorování v experimentálních povodích potvrdila existenci významného rozdílu $\mathrm{v}$ množství akumulovaného sněhu nejen v závislosti na nadmořské výšce, ale rovněž na vegetačním pokryvu, zejména mezi otevřenými plochami a lesem. Jedná se o okolnost, kterou lze jen obtížně postihnout použitím výsledků měření prováděných běžně na meteorologických stanicích. Zároveň byla dokázána i velmi výrazná variabilita $\mathrm{v}$ množství sněhu na různých stanovištích obdobného charakteru ve srovnatelné nadmořské výšce, což svědčí o značné složitosti procesu akumulace sněhové pokrývky a jejím významném ovlivnění značným množstvím faktorů. $\mathrm{Z}$ analýzy odtoku v profilu Rokytka-pod Rokyteckou slatí vyplývá, že hydrologický rok 2007 byl z hlediska výskytu a množství sněhové pokrývky značně specifický, stejně jako odtok z následného jarního tání. Nadprůměrné teploty vzduchu zejména v lednu 2007 neumožnily tvorbu obvyklého množství zásob sněhu a byly prŕíčinou výrazně nadprůměrného odtoku $\mathrm{v}$ tomto měsíci. Rok 2008 se z pohledu chodu odtoku během zimního a jarního období daleko více blížil průměrnému stavu. Výsledky sněhových kampaní by měly výrazně pomoci při zpřesnění odhadů zásob vody vyskytujících se ve sněhové pokrývce a pro následné simulace odtoku z ní za účelem precizace hydrologických předpovědí.

Obr. 1 - Lokalizace povodí Vydry a Křemelné se státními profily ČHMÚ a experimentálních povodí $\mathrm{s}$ instalovanými automatickými hladinoměrnými a srážkoměrnými zař́ízeními v rámci pramenné oblasti Otavy (závěrový profil Otava-Rejštejn). V legendě shora: hladinoměr PřF UK, limnigrafická stanice ČHMÚ, srážkoměr PřF UK, sídlo, vodní tok, hranice hlavního povodí, hranice experimentálního povodí.

Obr. 2 - Dlouhodobé průměrné denní $\left(Q_{d}\right)$ a měsíční průtoky $\left(Q_{m}\right) \quad v$ profilech Vydra-Modrava a Křemelná-Stodůlky $\mathrm{v}$ období 1.11.1999-31.10.2006 Osa $\mathrm{x}$ - měsíce, osa $\mathrm{y}$ - průtok $\left(\mathrm{m}^{3} \cdot \mathrm{s}^{-1}\right)$.

Obr. 3 - Výstup z automatického ultrazvukového hladinoměru a člunkového srážkoměru - reakce odtoku na příčinnou srážku v profilu Rokytka (pramenná oblast Vydry) v období 1.10.2006-20.5.2007 (v období 1.1.2007-28.3.2007 byl srážkoměr z technických důvodů mimo provoz). Osa y vlevo - úhrn srážek (mm), osa y vpravo - průtok $\left(\mathrm{m}^{3} \cdot \mathrm{s}^{-1}\right)$.

Obr. 4 - Porovnání variability odtoku ve dvou experimentálních povodích s rozdílným stupněm zrašelinění (Rokytka, Ptačí potok) v období 1.8.2006-31.5.2007. Osa $\mathrm{y}-\mathrm{Q} / \mathrm{Q}$.

Obr. 5 - Kolísání hladiny toku ve třech modelových povodích s rozdílným stupněm zrašelinění během extrémní povodňové situace v březnu 2008. Osa y - vodní stav $(\mathrm{mm})$.

Obr. 6 - Konzumpční křivka v profilu Rokytka. Osa $\mathrm{x}$ - průtok $\left(\mathrm{m}^{3} \cdot \mathrm{s}^{-1}\right)$, axis y - vodní stav $(\mathrm{mm})$.

Obr. 7 - Desetiminutové průtoky ve dvou modelových povodích $\mathrm{s}$ odlišným stupněm zrašelinění během extrémní povodňové události v březnu 2008 (vysoce zrašeliněné povodí je reprezentováno povodím Rokytky). Osa y - průtok $\left(\mathrm{m}^{3} \cdot \mathrm{s}^{-1}\right)$.

Obr. 8 - Prostorové rozložení výšky sněhové pokrývky (nahoře, $\mathrm{v} \mathrm{cm}$ ) a vodní hodnoty sněhu (v mm) v povodí Ptačího potoka dne 13.2.2007 (autor: Michal Jeníček). Horní mapa: v legendě shora: výška sněhové pokrývky v povodí Ptačího potoka, vodní tok, vrstevnice po $5 \mathrm{~m}$, hranice povodí, výška sněhové pokrývky $(\mathrm{cm})$. Dolní mapa, v legendě shora: vodní hodnota sněhu v povodí Ptačího potoka, vodní tok, vrstevnice po $5 \mathrm{~m}$, hranice povodí, vodní hodnota sněhu $(\mathrm{mm})$. Data: Databáze DMÚ25 - Vojenský geografický a hydrometeorologický úřad (http://geoportal.cenia.cz), DIBAVOD (VƯV T.G.M.). Souřadnicový systém: S-JTSK.

(Authors are with Charles University in Prague, Faculty of Science, Department of Physical Geography and Geoecology, Albertov 6, 12843 Praha 2, Czechia; email: jansky@natur.cuni.cz, kocum1@natur.cuni.cz.) 